\title{
UJI PRODUKTIVITAS JAMUR MERANG (Volvariella volvaceae) BIBIT F3 CILAMAYA DAN KONSENTRASI MEDIA TANAM AMPAS TAHU
}

\author{
(Productivity Test of Merang Mushrooms (Volvariella volvaceae) for F3 Cilamaya Seeds and \\ Concentration of Tofu Dregs Planting Media)
}

\author{
Gita Erina Apriyanti Widiyanto, Ani Lestari dan Yayu Sri Rahayu \\ Program Studi Agroteknologi, Fakultas Pertanian, Universitas Singaperbangsa Karawang \\ Jl. HS Ronggowaluyo, Teluk Jambe Timur, Kab. Karawang 41361 \\ Penulis Koresponden: gitaerina64@gmail.com
}

Article Submitted: 15-12-2020

Article Accepted: 10-01-2021

\begin{abstract}
Karawang is a rice center in West Java and National, rice straw potentially used as a media for merang mushroom to growth. In research, tofu plup planting media was carried out and tested the productivity of the merang mushroom F3 seedlings from Cilamaya. The purpose of the research to obtain the composition of the tofu plup growing media which gave the highest result towards merang mushroom growth. The research was conducted in Plant Biotechnology Laboratory, Faculty of Agriculture, Singaperbangsa Karawang University and in Kumbung (Mushroom House), Pasirmulya Village, Majalaya, Karawang. The method that being used was experimental, single factor randomized block design (RBD) of 6 treatments in 4 replications, the treatments were: A (Control + Straw 100\%), B (Tofu pulp 5\% + straw 95\%), C (Tofu plup 15\% + straw $85 \%$ ), D ( tofu pulp $25 \%+$ straw $75 \%$ ), E (tofu plup $35 \%+$ straw $65 \%$ ) and F (tofu pulp $45 \%+$ straw $55 \%)$. The results showed that treatment C (15\% tofu pulp $+85 \%$ straw) has the best value, there is a significant effect on the parameters of fruit body length of $6,98 \mathrm{~cm}$, fruit body diameter with a value of $18,22 \mathrm{~mm}$, number of fruit bodies with a value of 5,80 , fruit body weight $10,05 \mathrm{~g}$.
\end{abstract}

Keywords: Merang mushroom, F3 seeds, planting media, tofu dregs.

\section{PENDAHULUAN}

Kabupaten Karawang merupakan salah satu sentra padi di Jawa Barat dan Nasional, produksi padi yang melimpah akan menghasilkan jerami yang berpotensi untuk dijadikan media tumbuh jamur merang. Oleh karena itu, Karawang telah tumbuh sebagai sentra produksi jamur merang seperti lokasi Jatisari, Kotabaru, Cilamaya Wetan, Cilamaya Kulon, Rawamerta, dan Banyusari (Neng, 2012) dalam (Lestari et al., 2019).

Menurut (Nofitri 2014) dalam (Manik 2018), kendala yang sering dihadapi petani jamur merang yaitu sulitnya mendapatkan biakan murni karena mudah terkontaminasi dan memerlukan ruang steril yang bebas dari mikroba serta ketekunan dan ketelitian yang dibutuhkan untuk menghasilkan biakan murni dibandingkan dengan mendapatkan bibit F1, F2 dan F3.

Mengingat adanya persaingan untuk memperoleh limbah jerami padi tersebut karena limbah jerami padi tidak hanya digunakan untuk media tumbuh dalam budidaya jamur merang saja, tetapi limbah jerami digunakan sebagai pakan ternak, maka perlu adanya alternatif limbah lain yang dapat dijadikan media tumbuh jamur merang yang memiliki kandungan nutrisi yang sama ataupun yang lebih baik dan ketersediaannya melimpah di lingkungan sekitar (Bustamam, 2017). 
Menurut (Arma et al., 2013) dalam (Zahrotunnisa, 2019), Pemberian nutrisi tambahan pada media tanam jamur dapat meningkatkan pertumbuhan, perkembangan, pemunculan tubuh buah pada jamur dan produksi jamur. Pemberian nutrisi yang digunakan sebaiknya yang aman dikonsumsi yaitu limbah organik salah satunya yakni limbah ampas tahu (Zuhriyan, 2014) dalam (Zahrotunnisa, 2019).

Menurut (Hama 2018), ampas tahu merupakan limbah padat yang dihasilkan oleh industri pengelolaan kedelai menjadi tahu yang kurang dimanfaatkan, salah satu cara agar bernilai ekonomis dengan memanfaatkan sebagai pupuk organik, apabila limbah ampas tahu dibiarkan dapat berakibat terjadinya pencemaran lingkungan dan berbau tidak sedap.

Menurut (Rahayu et al., 2016), Proses pembuatan tahu tidak semua kandungan protein terekstrak apalagi jika menggunakan proses penggilingan sederhana dan tradisional, sehingga ampas tahu masih mempunyai kandungan protein yang relatif tinggi. Ampas tahu mengandung protein $43,8 \%$, lemak $0,9 \%$, serat kasar $6 \%$, kalsium $0,32 \%$, fosfor $0,67 \%$, magnesium 32,3 $\mathrm{mg} / \mathrm{kg}$ dan bahan lainnya. Ampas tahu mengandung unsur $\mathrm{N}$ rata-rata $16 \%$ dari protein yang dikandungnya. (Adiyuwono 2000) dalam (Romdhon 2012), protein berfungsi untuk merangsang pertumbuhan miselia, sedangkan lemak digunakan sebagai sumber energi untuk mengurai karbohidrat, protein, mineral dan vitamin.

Menurut (Umniyatie et al., 2013) dalam (Zahrotunnisa, 2019), bibit jamur yang disiapkan mulai dari bibit F1, F2 dan F3. F1 adalah bibit induk turunan pertama yang berasal dari inokulasi F0 (biakan murni). Bibit yang digunakan petani untuk budidaya jamur adalah F3, miselium cepat mengembang dan kuat, serta hasil produksi lebih baik. Bibit F3 mempunyai keuntungan dari segi harga yang lebih murah dibandingkan dengan bibit F1. Penggunaan keturunan bibit yang tepat diharapkan dapat mempercepat pertumbuhan miselium, dengan pertumbuhan yang baik maka menyebabkan proses penyerapan nutrisi yang terdapat pada media tumbuh akan meningkatkan produksi jamur merang, namun jamur merang membutuhkan media tanam yang banyak mengandung unsur hara sehingga dapat meningkatkan kualitas dan kuanitas jamur merang (Manik 2018).

Menurut (Mufarrihah 2009) dalam (Manik 2018), menyatakan bahwa ampas tahu masih banyak mengandung nutrisi seperti karbohidrat, protein, lemak, mineral dan vitamin. Menurut (Supriati 2005) dalam (Manik 2018), kandungan yang terdapat pada ampas tahu dari $100 \mathrm{~g}$ mengandung protein $17 \mathrm{~g}$, lemak 5,9 g, fosfor $29 \mathrm{~g}$ dan mineral $29 \mathrm{~g}$. Menurut (Rohmiyatul et al, 2010) dalam (Manik 2018), menambahkan bahwa kandungan nutrisi ampas tahu memiliki protein $21,3-27 \%$, serat kasar 16 - $23 \%$ dan lemak 4,5 - 17\%. Penelitian sebelumnya menunjukkan bahwa penggunaan ampas tahu $25 \%$ + ekstrak kulit kentang $40 \%$ memberikan hasil tertinggi pada jumlah rumpun buah per baglog $(1,83$ buah), jumlah tudung buah per rumpun $(24,44$ buah), diameter tudung buah maksimal per baglog $(14,91 \mathrm{~cm})$, panjang batang maksimal per baglog $(7,32 \mathrm{~cm})$, bobot basah jamur per baglog $(137,03 \mathrm{~g})$, dan intensitas panen per periode (1,39 kali) (Suryanika, 2019).

\section{METODOLOGI PENELITIAN}

Bahan yang akan digunakan dalam percobaan ini terdiri dari kentang, gula, agar-agar, jagung pipil, kapur pertanian, gula halus, alkohol 70\%, spirtus, aquades, jerami padi, kapas, dedak, kapur, air, ampas tahu dan bibit F3 jamur merang cilamaya dengan diameter $79,2 \mathrm{~mm}$. Alat yang digunakan dalam percobaan ini terdiri dari cawan petri, tabung reaksi, botol saus, scapel, blade, bunsen, korek api, plastik wrapping, gelas ukur, botol kultur jaringan, labu ukur 250 $\mathrm{ml}$, beaker glass $50 \mathrm{ml}$, laminar air flow, 
autoclave, panci, spatula, ember, garpu, timbangan, terpal, drum strerilisasi, kayu bakar, tungku, kompor, tabung gas, spreyer, karet, plastik dan blower.

Metode penelitian yang digunakan adalah metode eksperimen. Rancangan percobaan yang digunakan adalah Rancangan Acak Kelompok (RAK) faktor tunggal dengan enam kombinasi perlakuan dan empat kali ulangan, sehingga total terdapat sebanyak 24 unit percobaan untuk diamati. Kombinasi perlakuan terdiri dari : $\mathrm{A}=$ Tanpa penambahan ampas tahu $+100 \%$ jerami; $\mathrm{B}=5 \%$ ampas tahu $+95 \%$ jerami; $\mathrm{C}$ $=15 \%$ ampas tahu $+85 \%$ jerami; $\mathrm{D}=25 \%$ ampas tahu $+75 \%$ jerami; $\mathrm{E}=35 \%$ ampas tahu $+65 \%$ jerami dan $\mathrm{F}=45 \%$ ampas tahu $+55 \%$ jerami. Pengamatan terdiri dari panjang badan buah, diameter badan buah, jumlah badan buah, bobot badan buah, panen perhari, lama panen dan total produksi. Metode analisa menggunakan Rancangan Acak Kelompok (RAK) dengan rumus :

$$
\mathbf{Y i j}=\mathbf{U}+\mathbf{r i}+\mathbf{t} \mathbf{j}+\mathbf{e i j}
$$

Hasil analisis sidik ragam yang berbeda selanjutnya diuji dengan Duncan Multiple Range Test (DMRT).

\section{HASIL DAN PEMBAHASAN}

Pengamatan pertumbuhan dilakukan selama panen yaitu 21 hari. Hasil analisis sidik ragam menunjukkan berpengaruh nyata terhadap panjang badan buah, rata-rata panjang badan buah disajikan pada Tabel 1 .

Tabel 1. Rata-rata Panjang Badan Buah.

\begin{tabular}{clc}
\hline Kode & \multicolumn{1}{c}{ Perlakuan } & $\begin{array}{c}\text { Rata-rata Panjang } \\
\text { Badan Buah (cm) }\end{array}$ \\
\hline A & Kontrol + jerami 100\% & $6,67 \mathrm{ab}$ \\
B & Ampas tahu 5\% + jerami 95\% & $6,52 \mathrm{abc}$ \\
C & Ampas tahu 15\% + jerami 85\% & $6,98 \mathrm{a}$ \\
D & Ampas tahu 25\% + jerami 75\% & $6,16 \mathrm{bc}$ \\
E & Ampas tahu 35\% + jerami 65\% & $6,94 \mathrm{a}$ \\
F & Ampas tahu 45\% + jerami 55\% & $5,93 \mathrm{c}$ \\
\hline & Koefisien Keragaman (KK) & $7,06 \%$ \\
\hline
\end{tabular}

Keterangan : Nilai rata-rata yang diikuti huruf yang sama pada setiap kolom yang sama menunjukkan tidak berbeda nyata pada DMRT taraf 5\%.

Rata-rata pengamatan panjang badan buah pada tabel 1 menunjukkan bahwa perlakuan C (ampas tahu $15 \%$ + jerami $85 \%$ ) memberikan nilai tertinggi dengan rata-rata $6,98 \mathrm{~cm}$, namun perlakuan $\mathrm{F}$ (ampas tahu 45\% + jerami 55\%) memberikan nilai terendah dengan rata-rata $5,93 \mathrm{~cm}$.

Campuran ampas tahu dan jerami padi bersifat porous dibandingkan dengan ampas tahu saja, sehingga sirkulasi oksigen dan karbondioksida berjalan dengan baik. Oksigen dibutuhkan untuk pertumbuhan jamur merang terutama bagi pembentukan tubuh jamur. Hal ini sesuai dengan (Sinaga 2011), menyatakan bahwa jamur membutuhkan oksigen untuk pertumbuhan. Kebutuhan oksigen selama perkembangan miselium tidak terlalu besar, namun pada stadia pembentukan tubuh buah aerasi sangat dibutuhkan. Bila kekurangan oksigen tubuh buah akan kerdil. Konsentrasi media tanam jerami padi lebih tinggi dengan media tanam ampas tahu menghasilkan pertumbuhan dan hasil yang kurang maksimal karena berkurangnya kandungan selulosa yang berperan pada pertumbuhan 
dan hasil jamur merang. Hal ini sesuai dengan penelitian (Meriana et al. 2013).

Diameter badan buah menunjukkan bahwa menggunakan berbagai konsentrasi

Tabel 2. Rata-rata Diameter Badan Buah. media tanam ampas tahu memberikan pengaruh nyata, rata-rata diameter badan buah disajikan pada Tabel 2.

\begin{tabular}{ccc}
\hline \multirow{2}{*}{ Kode } & Perlakuan & Rata-rata Diameter Badan Buah (mm) \\
\hline A & Kontrol + jerami 100\% & $17,72 \mathrm{a}$ \\
B & Ampas tahu 5\% + jerami 95\% & $17,28 \mathrm{ab}$ \\
C & Ampas tahu 15\% + jerami 85\% & $18,22 \mathrm{a}$ \\
D & Ampas tahu 25\% + jerami 75\% & $16,16 \mathrm{bc}$ \\
E & Ampas tahu 35\% + jerami 65\% & $17,24 \mathrm{ab}$ \\
F & Ampas tahu 45\% + jerami 55\% & $15,41 \mathrm{c}$ \\
\hline & KK & $6 \%$ \\
\hline
\end{tabular}

Keterangan : Nilai rata-rata yang diikutihuruf yang sama pada setiap kolom yang sama menunjukkan tidak berbeda nyata pada DMRT taraf 5\%.

Rata-rata pengamatan diameter badan buah pada tabel 2 menunjukkan bahawa perlakuan C (ampas tahu 15\% + jerami $85 \%$ ) memberikan nilai rata-rata diameter badan buah tertinggi yaitu 18,22 $\mathrm{mm}$, sedangkan perlakuan $\mathrm{F}$ (ampas tahu $45 \%+$ jerami $55 \%$ ) memberikan nilai terendah yaitu $15,41 \mathrm{~mm}$.

Perlakuan C (ampas tahu 15\% + jerami $85 \%$ ) memberikan hasil diameter tertinggi, hal ini disebabkan karena media tumbuh jamur yang terdekomposisi secara

Tabel 3. Rata-rata Jumlah Badan Buah. cepat dan merata sehingga pertumbuhannya menjadi optimal. Mufarrihah (2009), menyatakan bahwa unsur hara yang terdapat pada media, seperti $\mathrm{C}, \mathrm{N}, \mathrm{P}$ dan $\mathrm{K}$ dapat diserap oleh jamur dengan baik. Cepat menyerapnya unsur hara menyebabkan miselium cepat tumbuh dan berkembang.

sHasil analisis sidik ragam pada jumlah badan buah menunjukkan pengaruh nyata, rata-rata jumlah badan buah disajikan pada Tabel 3.

\begin{tabular}{clc}
\hline \multirow{2}{*}{ Kode } & \multicolumn{1}{c}{ Perlakuan } & Rata-rata Jumlah Badan Buah \\
\hline A & Kontrol + jerami 100\% & $5,62 \mathrm{ab}$ \\
B & Ampas tahu 5\% + jerami 95\% & $4,12 \mathrm{abc}$ \\
C & Ampas tahu 15\% + jerami 85\% & $5,80 \mathrm{a}$ \\
D & Ampas tahu 25\% + jerami 75\% & $3,90 \mathrm{abc}$ \\
E & Ampas tahu 35\% + jerami 65\% & $3,82 \mathrm{bc}$ \\
F & Ampas tahu 45\% + jerami 55\% & $3,43 \mathrm{c}$ \\
\hline & KK & $26,50 \%$ \\
\hline
\end{tabular}

Keterangan : Nilai rata-rata yang diikuti huruf yang sama pada setiap kolom yang sama menunjukkan tidak berbeda nyata pada DMRT taraf 5\%. 
Rata-rata pengamatan jumlah badan buah pada tabel 3 menunjukkan bahwa perlakuan C (ampas tahu $15 \%$ + jerami $85 \%$ ) memberikan nilai tertinggi rata-rata jumlah badan buah yaitu 5,80, namun perlakuan $\mathrm{F}$ memberikan nilai terendah yaitu 3,43 .

Pada perlakuan C (ampas tahu 15\% + jerami $85 \%$ ) kandungan nutrisi yang telah mengalami dekomposisi dengan cepat menjadikan unsur nutrisi yang terdapat dalam media cepat terurai sehingga kemunculam primordia mampu menghasilkan waktu pemunculan tercepat. Hal ini diperjelas dengan pendapat Tutik (2004) yang menyatakan bahwa pertumbuhan miselium terbaik akan mempengaruhi kecepatan pembentukan primordia yang diawali dengan pembentukan miselium, jika promordia banyak maka jumlah badan buah akan banyak, sedangkan perlakuan $\mathrm{F}$ (ampas tahu $45 \%+$ jerami 55\%) memberikan hasil pertumbuhan paling lambat. Hal ini diduga karena kecepatan waktu kemunculan miselium lambat yang menyebabkan waktu kemunculan primordia menjadi terhambat, karena pertumbuhan primordia sangat dipengaruhi oleh pertumbuhan miselium.

Bobot badan buah menunjukkan bahwa menggunakan berbagai konsentrasi media tanam ampas tahu memberikan pengaruh nyata, rata-rata bobot badan buah disajikan pada Tabel 4.

Tabel 4. Rata-rata Bobot Badan Buah.

\begin{tabular}{clc}
\hline Kode & \multicolumn{1}{c}{ Perlakuan } & $\begin{array}{c}\text { Rata-rata Bobot } \\
\text { Badan Buah }(\mathrm{g})\end{array}$ \\
\hline A & Kontrol + jerami 100\% & $9,47 \mathrm{a}$ \\
B & Ampas tahu 5\% + jerami 95\% & $9,23 \mathrm{a}$ \\
C & Ampas tahu 15\% + jerami 85\% & $10,05 \mathrm{a}$ \\
D & Ampas tahu 25\% + jerami 75\% & $8,08 \mathrm{a}$ \\
E & Ampas tahu 35\% + jerami 65\% & $8,94 \mathrm{a}$ \\
F & Ampas tahu 45\% + jerami 55\% & $5,53 \mathrm{~b}$ \\
\hline & KK & $14,01 \%$ \\
\hline
\end{tabular}

Keterangan : Nilai rata-rata yang diikuti huruf yang sama pada setiap kolom yang sama menunjukkan tidak berbeda nyata pada DMRT taraf $5 \%$.

Rata-rata pengamatan bobot badan buah pada tabel 4 menunjukkan bahawa perlakuan C (ampas tahu 35\% + jerami $85 \%$ ) memperoleh rata-rata tertinggi dengan nilai $10,05 \mathrm{~g}$, namun perlakuan $\mathrm{F}$ memberikan nilai terendah yaitu 5,53 g.

Menurut hasil penelitian Mufarrihah (2009), ampas tahu memiliki kandungan fosfor, nitrogen, dan kalium yang tinggi sehingga unsur-unsur tersebut dapat mempercepat proses pertumbuhan miselium yang akan berkorelasi terhadap pertumbuhan tubuh buah dan produksi jamur.

Riyanti dan Sumarsih (2002) dalam Shifriyah et al., (2012), dengan pemberian nutrisi sampai tingkat tertentu akan mensuplai nutrien, tetapi dengan pemberian yang berlebih akan menurunkan kandungan lignoselulosa dalam meningkatkan berat pada jamur.

\section{KESIMPULAN}

Kandungan protein yang terdapat pada ampas tahu dapat mensubtitusi media tanam jerami padi. Konsentrasi terbaik diperoleh pada perlakuan C (ampas tahu $15 \%$ + jerami $85 \%$ ), sedangkan perlakuan $\mathrm{F}$ (ampas tahu 45\% + jerami 55\%) menghasilkan produksi jamur merang yang 
terendah karena berkurangnya kandungan selulosa yang berperan pada pertumbuhan dan hasil jamur merang.

\section{UCAPAN TERIMAKASIH}

Dekan Fakultas Pertanian Unsika Muharam Ir,. M.P, yang telah memberikan ijin melakukan penelitian di laboratorium Bioteknologi Tanaman dan Ani Lestari sebagai pembimbing utama yang telah mendanai penelitian ini, serta Yayu Sri Rahayu sebagai pembimbing pendamping.

\section{DAFTAR PUSTAKA}

Bustamam, A. 2017. Pertumbuhan Jamur Merang (Volvariella volvaceae) Pada Media Tanam Jerami Padi dan Limbah Sekam. Skripsi. Fakultas Keguruan dan Ilmu Pendidikan Universitas Syiah Kuala Aceh. Aceh.

Hama, S. 2018. Pemanfaatan Kompos Ampas Tahu Pada Pertumbuhan Dan Produksi Tanaman Kacang Tanah (Arachis hypogaea L.). Jurnal Perbal 6 (3) : 48-58.

Lestari, A., Nurcahyo W.S., dan Rakim A. 2019. Uji Laju Pertumbuhan Miselia Jamur Merang (Volvariella volvaceae) Lokasi Purwasari Terhadap Jenis Media Biakan Murni Dan Umur Panen Yang Berbeda. Jurnal Agrotek Indonesia 4 (1): 4449.

Manik, D. 2018. Pengaruh Pemberian Ampas Tahu Dan Sumber Bibit Terhadap Pertumbuhan Dan Produksi Jamur Tiram Putih (Pleurotus ostreatus). Skripsi. Fakultas Pertanian Universitas Medan Area. Medan.

Romdhon, Riapsari. 2012. Pemanfaatan Ampas Tahu Sebagai Campuran Media Tanam Terhadap Kecepatan Waktu Tumbuh Jamur Tiram Putih
(Pleurotus ostreatus). Surakarta. Fakultas Keguruan dan Ilmu Pendidikan. Universitas Muhammadiyah Surakarta.

Shifriyah, A., Badami, K., dan Suryawati., S. 2012. Pertumbuhan dan Produksi Jamur Tiram Putih (Pleurotus ostreatus) pada Penambahan Dua Sumber Nutrisi. Jurnal Agrovigor 5 (1) : 8-13.

Sinaga, M. 2011. Budidaya Jamur Merang. Penebar Swadaya, Jakarta.

Merina, N., A.H. Bakrie., K.F. Hidayat. 2013. Pengaruh Komposisi Media Ampas Tahu Dan Jerami Padi Pada Pertumbuhan Dan Hasil Jamur Merang (Volvariela volvaceae). Jurnal Agrotek Tropika 1 (3) : 259263.

Mufarrihah, L. 2009. Pengaruh Penambahan Bekatul Dan Ampas Tahu Pada Media Terhadap Pertumbuhan Dan Produksi Jamur Tiram Putih (Pleurotus ostreatus). Skripsi Universitas Islam Negeri Malang. Malang.

Rahayu, L.H., R.W. Sudrajat., E. Rinihapsari. 2016. Teknologi Pembuatan Tepung Ampas Tahu Untuk Produksi Aneka Makanan Bagi Ibu-Ibu Rumah Tangga Di Kelurahan Gunungpati, Semarang. Jurnal Pengabdian Kepada Masyarakat 7 (1) : 68-76.

Suryanika, Anggi. 2019. Pengaruh Kombinasi Penambahan Media Tanam dan Nutrisi Organik Terhadap Produksi Jamur Tiram Putih (Pleurotus ostreatus). Skripsi. Fakultas Pertanian. Universitas Singaperbangsa Karawang. 
Tutik, L.A. 2004. Penambahan Tongkol Jagung Dan Tetes Tebu Pada Media Serbuk Gergaji Terhadap Pertumbuhan Jamur Kuping. Skripsi. Malang: Fakultas Pertanian Universitas Muhammadiyah Malang

Zahrotunnisa, Siti. 2019. Pengaruh Proporsi Subtitusi Ampas Tahu pada Media
Tanam Terhadap Pertumbuhan dan Hail Jamur Tiram Putih (Pleurotus ostreatus). Skripsi. Fakultas Pertanian. Universitas Singaperbangsa Karawang. Karawang. 